\title{
SNP analysis reveals estrogen receptor 1 (ESR1) gene variants associated with laying traits in quails
}

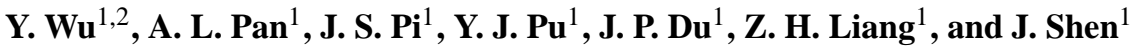 \\ ${ }^{1}$ Institute of Animal Science and Veterinary Medicine, Hubei Academy of Agricultural Science, \\ Wuhan 430064, China \\ ${ }^{2}$ Hubei Key Laboratory of Animal Embryo and Molecular Breeding, Wuhan 430064, China
}

Correspondence to: J. P. Du (youngwuyan@163.com)

Received: 14 July 2015 - Revised: 26 October 2015 - Accepted: 19 November 2015 - Published: 26 November 2015

\begin{abstract}
In this study, the estrogen receptor 1 (ESRl) gene was studied as a candidate gene for laying traits of two quail populations (the yellow-feather quail and chestnut-feather quail). Five pairs of primers were designed to detect single-nucleotide polymorphisms (SNPs) of exon 1, 2, 4, 8 and intron 1 of the ESRl gene by polymerase chain reaction (PCR)-restriction fragment length polymorphism (RFLP) and sequencing methods. Only the products amplified from exon 8 displayed polymorphism. The results showed one novel variation: a variation in exon 8 of ESRl gene (g.91C > T, KC977991 and KC977992). It was associated with some laying traits in two quail populations including egg weight, the age of first egg and egg number at 20 weeks. And the CC genotype was associated with superior egg number at 20 weeks. Therefore, we speculated that the variation in exon 8 of ESRl gene may have an effect on laying traits in the abovementioned quail populations.
\end{abstract}

\section{Introduction}

Laying performance is an economically important trait in egg-producing birds and is always of primary concern during breeding. This has led commercial breeders to incorporate significant selection for increased laying performances in breeding programmers. The quest for improved egg production is an important focus of poultry breeding and management (Kang et al., 2009). Estrogen is known to be involved in the regulation of oogenesis, vitellogenesis, gonadotropin regulation, testicular development and other aspects of reproduction, in addition to having regulatory roles in many organ systems (Gustafsson, 2003; Heldring et al., 2007; Hess et al., 2003; Muriach et al., 2008; Nilsson et al., 2001). The biological actions of estrogens are manifested through two high-affinity estrogen receptors (ESRs), estrogen receptor alpha and estrogen receptor beta (Gruber et al., 2004; Kuiper et al., 1996). ESRs belong to the nuclear receptor superfamily, a family containing receptors for small molecules (steroids, thyroid hormones, rexinoids, oxysterols, etc.) with a defined domain structure (Nelson and Habibi, 2013). ESRs are also thought to play a central role in the regulation of many life processes, including development, reproduction and normal physiology (Böttner et al., 2014). The role of ESRI and ESR2 in the reproductive performance of poultry has been increasingly studied in recent years (Tang et al., 2009; Wang et al., 2012). ESRl gene is one of the candidate genes for detecting polymorphisms associated with the reproductive and laying traits in pigs, chickens and other animals (Goliasova and Wolf, 2004; Humpolicek et al., 2007; Liu et al., 2010; Muñoz et al., 2007; Tang et al., 2009; Wang et al., 2012; Bi et al., 2005; Szreder and Zwierzchowski, 2007; Wu et al., 2014). The objectives of this study were to detect the polymorphism in five regions (exons 1, 2, 4, 8 and intron 1) of ESR gene in quail populations (the yellow-feather and chestnut-feather quails), which are bred in China and have relatively high laying performance and mature early (about 45 days), and to investigate its association with laying traits of two populations and further search the possibility of ESRl gene being used as molecular genetic markers for laying traits. 
Table 1. Primer sequence, product size and annealing temperature used in analyses of quail ESR gene.

\begin{tabular}{llllr}
\hline Primer name & Product size $(\mathrm{bp})$ & Primer sequence $\left(5^{\prime}-3^{\prime}\right)$ & $\begin{array}{l}\text { Amplified } \\
\text { region }\end{array}$ & $\begin{array}{r}\text { Annealing } \\
\text { temperature }\left({ }^{\circ} \mathrm{C}\right)\end{array}$ \\
\hline P1 & 382 & $\begin{array}{l}\text { F: CAAAGCCTCTGGAGTTAC } \\
\text { R: CAAAGCTGCCCTGTTCAT }\end{array}$ & Exon 1 & 54.1 \\
P2 & 161 & $\begin{array}{l}\text { F: CAAGCTCTGATAATAGGCG } \\
\text { R: AGCCCTCACAAGACCAGAC }\end{array}$ & Exon 2 & 58.8 \\
P3 & 303 & $\begin{array}{l}\text { F: GCGGGCGAATGATGAAACA } \\
\text { R: GCCCAGTTGATCATGTGCA }\end{array}$ & Exon 4 & 57.6 \\
P4 & 213 & $\begin{array}{l}\text { F: CAACAAAGGAATGGAGCA } \\
\text { R: CCTCTTCTTTGCTGTTAA }\end{array}$ & Exon 8 & 53.6 \\
P5 & 161 & $\begin{array}{l}\text { F: CAAGCTCTGATAATAGGCG } \\
\text { R: AGCCCTCACAAGACCAGAC }\end{array}$ & Intron 1 & 58.0 \\
& & & \\
\hline
\end{tabular}

\section{Materials and methods}

\subsection{Sample collection}

Two quail populations (the yellow-feather quails, 192, and the chestnut-feather quails, 192) were used in this study for initial single-nucleotide polymorphism (SNP) discovery. The two populations were raised on the same farm and selected for 10 years for different feather color and laying performance. The yellow-feather quail has higher egg weight, and the chestnut-feather quail has higher egg number. All birds were raised under identical environmental conditions: in cages and fed commercial corn-soybean diets that met quails' requirements. Blood samples (collected from 14th generation) and phenotypic data on laying traits (the weight of first egg, the age of first egg, egg weight, the weight at 20 weeks and the egg number at 20 weeks) were collected from the 384 individuals. Genomic DNA was obtained by phenol and chloroform $(1: 1)$ extraction, and stored at $-20^{\circ} \mathrm{C}$.

\subsection{Primer design and PCR amplification}

According to chicken ESRl gene sequences (GenBank accession no. NC_006090), five pairs of primers (Table 1) were designed to amplify the quail ESRI gene exon 1, 2, 4, 8 and intron 1 regions and detect the SNP of the five regions.

The polymerase chain reaction (PCR) was performed by mixing $40 \mathrm{ng}$ of genomic DNA, $0.5 \mathrm{pmol}$ of each of forward and reverse primer, $1.5 \mu \mathrm{L}$ of $10 \times$ buffer, $1.5 \mathrm{mM}$ of $\mathrm{MgCl}_{2}$, $0.25 \mathrm{mM}$ of each dNTP, and $1.5 \mathrm{U}$ of Taq DNA polymerase (Fermentas, Shenzhen, China) in a $15 \mu \mathrm{L}$ volume, and run on an Eppendorf Mastercycler gradient (Eppendorf, Hamburg, Germany) according to the following program: $95^{\circ} \mathrm{C}$ for $5 \mathrm{~min} ; 35$ cycles of $94^{\circ} \mathrm{C}$ for $30 \mathrm{~s}$, annealing of $X^{\circ} \mathrm{C}$ (Table 1) for $35 \mathrm{~s}$, and $72^{\circ} \mathrm{C}$ for $45 \mathrm{~s}$; and final extension step at $72^{\circ} \mathrm{C}$ for $10 \mathrm{~min}$.

\subsection{SNP identification and genotyping}

Genomic DNA from the yellow-feather quails and chestnutfeather quails was used as a template to amplify with the five pairs of primers (exon 1, 2, 4, 8 and intron 1), and the sequences were aligned to search for base variations.

The polymorphisms in quail ESRl were analyzed by PCRRFLP (restriction fragment length polymorphism), which was performed by mixing $8 \mu \mathrm{L}$ of PCR product (with primer exon 8), $10 \mathrm{U}$ of the restriction enzyme AccI (Fermentas, Shenzhen, China) and $1 \mu \mathrm{L}$ corresponding $10 \times$ reaction buffer, and incubated at $37^{\circ} \mathrm{C}$ for $12 \mathrm{~h}$, and then separated at $125 \mathrm{~V}$ on a $3 \%$ agarose gel.

\subsection{Statistical analysis}

The genotypic frequencies were calculated, and the HardyWeinberg equilibrium for each breed was analyzed using $\chi^{2}$ test of PopGene32 (version 1.31). The traits were compared among the genotypes. The association of ESRI genotypes with laying traits including the weight of first egg, the age of first egg, egg weight, the weight at 20 weeks and the egg number at 20 weeks were evaluated according to two-way analysis of software SPSS (version 16.0), using the following model:

$Y=\mu+G+L+G \times L+e$,

where $Y$ is the dependent variable (analyzed traits); $\mu$ was the overall mean; genotype $(G)$ of ESRI exon 8 (CC, CT and TT), the quail population $(L)$, interactions between genotype and quail population $(G \times L)$ were the fixed effects; and $e$ was the random error. Difference between genotypes was determined by least squares.

\section{Results}

\subsection{Polymorphism identification and detection}

The sequences amplified with five pairs of primers (P1, P2, P3, P4 and P5 for exon 1, 2, 4, 8 and intron 1) were aligned 
Table 2. Allele and genotype frequencies at exon 8 locus of ESR gene in two quail populations.

\begin{tabular}{|c|c|c|c|c|c|c|c|}
\hline \multirow[t]{2}{*}{ Breeds } & \multirow[t]{2}{*}{ Number } & \multicolumn{3}{|c|}{ Genotype frequencies } & \multicolumn{2}{|c|}{ Gene frequencies } & \multirow[t]{2}{*}{$\chi^{2}(\mathrm{HWE})$} \\
\hline & & $\mathrm{CC}$ & TT & TC & $\mathrm{C}$ & $\mathrm{T}$ & \\
\hline Yellow-feather quail & 192 & 0.5625 & 0.0208 & 0.4167 & 0.7708 & 0.2292 & $6.1018^{*}$ \\
\hline Chestnut-feather quail & 192 & 0.5625 & 0.0625 & 0.3750 & 0.7500 & 0.2500 & 1.3932 \\
\hline
\end{tabular}

Note: $\chi 2$ (HWE): Hardy-Weinberg equilibrium $\chi 2$ value; ${ }^{*}$ showed that $P<0.01$ and the SNP locus in the population was not at Hardy-Weinberg equilibrium.

Table 3. Least square means and standard errors of the laying traits in two quail populations.

\begin{tabular}{lcccr}
\hline Traits & \multicolumn{4}{c}{ Yellow-feather quail (mean $\pm \mathrm{SE})$} \\
\cline { 2 - 5 } & $\mathrm{CC}(n=96)$ & $\mathrm{TT}(n=28)$ & $\mathrm{CT}(n=68)$ & $P$ value \\
\hline The weight of first egg $(\mathrm{g})$ & $137.58 \pm 2.39$ & $139.28 \pm 4.17$ & $139.82 \pm 2.78$ & 0.819 \\
The age of first egg (d) & $44.96 \pm 0.76^{\mathrm{b}}$ & $47.43 \pm 1.68^{\mathrm{ab}}$ & $49.41 \pm 0.85^{\mathrm{a}}$ & 0.007 \\
Egg weight $(\mathrm{g})$ & $10.74 \pm 0.20$ & $10.78 \pm 0.27$ & $10.90 \pm 0.28$ & 0.880 \\
The weight at 20 weeks (g) & $155.95 \pm 2.78$ & $160.00 \pm 4.93$ & $157.00 \pm 2.72$ & 0.762 \\
The egg number at 20 weeks & $86.33 \pm 1.39^{\mathrm{a}}$ & $81.86 \pm 0.86^{\mathrm{a}}$ & $73.94 \pm 1.70^{\mathrm{b}}$ & 0.001 \\
\hline Traits & \multicolumn{3}{c}{ Chestnut-feather quail (mean $\pm \mathrm{SE})$} \\
\cline { 2 - 5 } & $\mathrm{CC}(n=96)$ & $\mathrm{TT}(n=16)$ & $\mathrm{CT}(n=80)$ & $P$ value \\
\hline The weight of first egg (g) & $143.54 \pm 1.43$ & $144.25 \pm 2.28$ & $140.05 \pm 2.40$ & 0.390 \\
The age of first egg (d) & $45.33 \pm 0.53$ & $45.00 \pm 1.29$ & $45.05 \pm 0.75$ & 0.942 \\
Egg weight (g) & $9.83 \pm 0.44^{\mathrm{a}}$ & $8.08 \pm 0.62^{\mathrm{b}}$ & $9.82 \pm 0.53^{\mathrm{a}}$ & 0.006 \\
The weight at 20 weeks (g) & $153.58 \pm 2.26$ & $153.25 \pm 2.28$ & $148.55 \pm 2.69$ & 0.419 \\
The egg number at 20 weeks & $88.13 \pm 1.28^{\mathrm{a}}$ & $84.25 \pm 1.63^{\mathrm{ab}}$ & $82.90 \pm 0.98^{\mathrm{b}}$ & 0.009 \\
\hline
\end{tabular}

Note: different superscript letters (a and b) were significantly different (least significant difference test, $P<0.05$ ) in genotypes $\mathrm{CC}$, TT and CT; $n$ was the number of the genotype in the population.

among yellow-feather quails and chestnut-feather quails. No base variation was found in exon $1,2,4$ and intron 1 . There was one variation locus in exon $8, \mathrm{C} \rightarrow \mathrm{T}$ at the nucleotide position 91 (g.91C > T), which was synonymous and did not result in an amino acid change. But this variation locus changed the recognition site of restriction endonucleases AccI. This polymorphism can be detected by PCR-RFLP using the amplification product of primer $\mathrm{P} 4$. The sequences having variation in exon 8 were submitted to GenBank (accession number: KC977991, for CC genotype, and KC977992, for TT genotype). As shown in Fig. 1, $C$ to $T$ variation at locus 91 expressed three genotypes: CC, CT and TT.

\subsection{Allele and genotype distribution of ESR1 gene exon 8}

Allele and genotype frequencies of ESRI gene exon 8 in two quail populations are listed in Table 2 . The results indicate that at 91 loci, $C$ allele is preponderant allele in yellowfeather quail and chestnut-feather quail. The yellow-feather quail population deviated from Hardy-Weinberg equilibrium $(P<0.01)$, and the chestnut-feather quail population was in accordance with Hardy-Weinberg equilibrium $(P>0.05)$.

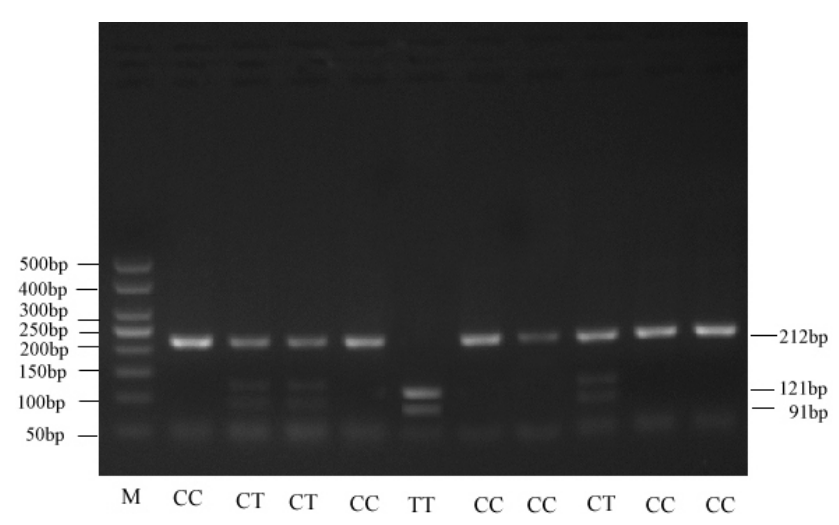

Figure 1. PCR-RFLP band pattern on a $3 \%$ agarose gel. The TT genotype has two bands (121 and $91 \mathrm{bp}$ ) which run fast; the CC genotype has one band (212 bp) which runs slowly; the CT genotype has three bands $(212,121$ and $91 \mathrm{bp})$, with one running slowly and the others running fast. 


\subsection{Association of polymorphism with laying traits at ESR1 gene exon 8}

The results of association analysis between different genotypes and laying traits of two quail populations are given in Table 3.

For chestnut-feather quails, there were significant differences between genotype TT and CC or CT for egg weight and between genotype $\mathrm{CC}$ and $\mathrm{CT}$ for the egg number at 20 weeks $(P<0.05)$. For yellow-feather quail, there were significant differences between genotype $\mathrm{CC}$ and $\mathrm{CT}$ for the age of first egg and between genotype CC or TT and CT for the egg number at 20 weeks $(P<0.05)$. Furthermore, no significant association of different genotypes with other traits were detected $(P>0.05)$.

\section{Discussions}

In this study, one variation in exon 8 of ESRI gene was discovered. The analyzed results suggested significant association of the exon 8 of ESRI gene variation in determining quails' egg weight, the age of first egg and egg number at 20 weeks. And the CC genotype was associated with superior egg number at 20 weeks. Moreover, further birds or other quail breeds need to be tested in order to validate both the associations found and the physiological significance of the variation. Considered overall, we speculated the variation in exon 8 of ESR1 gene may be having an effect on laying traits and could be used as a molecular marker to carry out selective breeding for quails.

Acknowledgements. This paper was supported by the Natural Science Foundation for young scholar of Hubei Academy of Agricultural Sciences (grant no. 2012NKYJJ11) and the open project of Hubei Key Laboratory of Animal Embryo and Molecular Breeding (grant no. 2015ZD146).

Edited by: K. Wimmers

Reviewed by: two anonymous referees

\section{References}

Bi, X. D., Chu, M. X., Jin, H. G., Fang, L., and Ye, S. C.: Estrogen receptor as a candidate gene for prolificacy of small tail Han sheep, Yi Chuan Xue Bao, 32, 1060-1065, 2005.

Böttner, M., Thelen, P., and Jarry, H.: Estrogen receptor beta: Tissue distribution and the still largely enigmatic physiological function, J. Steroid Biochem., 139, 245-251, 2014.

Goliasova, E. and Wolf, J.: Impact of the ESR gene on litter size and production traits in Czech Large White pigs, Anim. Genet., 35, 293-297, 2004.

Gruber, C. J., Gruber, D. M., Gruber, I. M., Wieser, F., and Huber, J. C.: Anatomy of the estrogen response element, Trends Endocrin. Met., 15, 73-78, 2004.
Gustafsson, J. A.: What pharmacologists can learn from recent advances in estrogen signaling, Trends Pharmacol. Sci., 24, 479485, 2003.

Heldring, N., Pike, A., Andersson, S., Matthews, J., Cheng, G., Hartman, J., Tujague, M., Ström, A., Treuter, E., Warner, M., and Gustafsson, J. A.: Estrogen receptors: how do they signal and what are their targets, Physiol. Rev., 87, 905-931, 2007.

Hess, R. A.: Estrogen in the adult male reproductive tract: a review, Reprod. Biol. Endocrin., 1, p. 52, 2003.

Humpolicek, P., Urban, T., Matousek, V., and Tvrdon, Z.: Effect of estrogen receptor, follicle stimulating hormone and myogenin genes on the performance of Large White sows, Czech Journal of Animal Science, 52, 334-340, 2007.

Kang, B., Guo, J. R., Yang, H. M., Zhou, R. J., Liu, J. X., Li, S. Z., and Dong, C. Y.: Differential expression profiling of ovarian genes in prelaying and laying geese, Poultry Sci., 88, 1975-1983, 2009.

Kuiper, G. G., Enmark, E., Pelto-Huikko, M., Nilsson, S., and Gustafsson, J. A.: Cloning of a novel receptor expressed in rat prostate and ovary, P. Natl. Acad. Sci. USA, 93, 5925-5930, 1996.

Liu, X., Chamba, Y. Z., Wang, Q., Ling, Y., Gu, X. D., Wu, K. L., and Zhang, H.: Effects of multi-genes for reproductive traits in Tibet pig, Hereditas, 32, 480-485, 2010.

Muñoz, G., Ovilo, C., Estelle, J., Silio, L., Fernandez, A., and Rodriguez, C.: Association with litter size of new polymorphisms on ESR1 and ESR2 genes in a Chinese-European pig line, Genet. Sel. Evol., 39,195-206, 2007.

Muriach, B., Carrillo, M., Zanuy, S., and Cerda-Reverter, J. M.: Distribution of estrogen receptor 2 mRNAs (Esr2a and Esr2b) in the brain and pituitary of the sea bass (Dicentrarchus labrax), Brain Res., 1210, 126-141, 2008.

Nelson, E. R. and Habibi, H. R.: Estrogen receptor function and regulation in fish and other vertebrate, Gen. Comp. Endocr., 192, 15-24, 2013.

Nilsson, S., Mäkelä, S., Treuter, E., Tujague, M., Thomsen, J., Andersson, G., Enmark, E., Pettersson, K., Warner, M., and Gustafsson, J. A.: Mechanisms of estrogen action, Physiol. Rev., 81, 1535-1565, 2001.

Szreder, T. and Zwierzchowski, L.: Estrogen receptors and their genes - potential markers of functional and production traits of farm animals, Mol. Biol. Rep., 34, 207-211, 2007.

Tang, Q. P., Zhu, W. Q., Wu, X., Li, H. F., Chen, K. W., and Zhao, D. W.: Research on the association between the polymorphism of ESR gene and egg performance in Wenchang Chicken, J. Yunnan Agricultural University, 24, 67-70, 2009.

Wang, H. C., Song, T. Y., and Yuan, X. C.: coreelation analysis between polymorphism of ESR gene and Laying performance in Zhuanghe Dagu Chicken, Chinese Agricult. Sci. B., 28, 43-46, 2012.

Wu, Y., Xiao, H. W., Liang, Z. H., Pan, A. L., Shen, J., Pi, J. S., $\mathrm{Pu}$, Y. J., Du, J. P., and Chen, Z. H.: Differential expression profiling of estrogen receptor in the ovaries of two egg duck (Anas platyrhynchos) breeds, Czech J. Anim. Sci., 59, 238-243, 2014. 